\title{
Placebo control group in COVID-19 vaccine trials: context and timing matters
}

\author{
Rafael Dal-Ré 1 [0
}

Received: 17 November 2021 / Accepted: 20 November 2021 / Published online: 27 November 2021

○ The Author(s), under exclusive licence to Springer-Verlag GmbH Germany, part of Springer Nature 2021

Keywords Placebo-controlled trials · Vaccines · COVID-19 - Ethics · Emergency use authorization Low- and middleincome countries

The debate about when placebo comparators in COVID-19 vaccine trials will no longer be acceptable goes on. A number of recent articles have argued that placebo-controlled randomized clinical trials (RCTs) are becoming infeasible and not ethically acceptable anymore [1-5]. The main ethical objection relies on the non-fulfillment of the clinical equipoise principle [6], once temporarily authorized COVID-19 vaccines are available (e.g., emergency use authorization in the USA, conditional marketing authorization in the EU, emergency use listing by WHO). Clinical equipoise requires that participants will be allocated to an intervention that is not inferior to any available alternative: so, placebo-controlled RCTs must not be allowed anymore when assessing novel COVID-19 vaccine candidates. Yet, context matters greatly. This approach is acceptable if we limit this contention to countries with adequate access to temporarily authorized COVID-19 vaccines, i.e., to highincome countries.

Today, regrettably, hundreds of millions of individuals that live in low- and middle-income countries lack access to temporarily authorized COVID-19 vaccines due to limited vaccine availability and will do so well into 2023 [7]. However, in these territories, and until sufficient knowledge on immunogenicity, safety and efficacy of multiple COVID19 vaccines is gathered, especially with the widespread of different SARS-CoV-2 variants of concern, double-blind placebo-controlled trials can and should be considered in the clinical development of new COVID-19 vaccine candidates [8-10]. In these trials, participants should only be included

Rafael Dal-Ré

rafael.dalre@quironsalud.es

1 Epidemiology Unit, Health Research Institute-Fundación Jiménez Díaz University Hospital, Universidad Autónoma de Madrid, Madrid, Spain with fully informed consent and the best possible standard of COVID-19 care must be available to all participants. As soon as the safety and efficacy of the vaccine candidate is demonstrated, participants should have the chance to be unblinded immediately and placebo recipients immunized with the vaccine candidate. Participants should be allowed to unblind and access a known effective vaccine should one become available to them. In addition, and in particular, the research should respond to local needs (placebo-controlled trials should be done in regions impacted with high burden of COVID-19), both participants and communities should benefit from the trial, and the vaccine candidate to be tested, if proved to be efficacious and safe, should be made available in the country where the trial is conducted [8]. To this end and from the very beginning, transparency should be the fundamental guiding principle in the cooperation between the sponsor and local stakeholders with full community partnership and engagement throughout. The commitment of local investigators, research ethics committees, and health authorities as well as of local community leaders is a must to ensure a fruitful community engagement and participation.

\section{Placebo-controlled RCTs in current COVID-19 vaccine candidates' development}

A review of the WHO databases $[11,12]$ showed that a number of phase 3 placebo-controlled RCTs in naïve healthy adults are currently being conducted (or should be started soon) in low- and middle-income countries with limited access to temporarily authorized COVID-19 vaccines. The main features of this type of trial and the percentage of the population that have been, at least, partially vaccinated in participating countries, as a proxy of availability of temporarily authorized COVID-19 vaccines, are shown in Table 1. 
Table 1 Large phase 3 randomized placebo-controlled trials in healthy naïve $\geq 18$-year-old individuals assessing COVID-19 vaccine candidates: trials to be started after 1 April $2021^{\text {a }}$ (data captured from the registries as of 16 November 2021)

\begin{tabular}{|c|c|c|c|c|c|c|}
\hline Trial & Sponsor & $\begin{array}{l}\text { Vaccine candidate } \\
\text { type }\end{array}$ & Study start date & $\mathrm{N}$ & Last update & $\begin{array}{l}\text { Participating } \\
\text { countries }(\%)^{\mathrm{b}}\end{array}$ \\
\hline \multicolumn{7}{|l|}{ Trials already stared } \\
\hline IRCT20210303050558N $1^{\mathrm{c}}$ & $\begin{array}{l}\text { Pasture Institute } \\
\text { (Iran) }\end{array}$ & $\begin{array}{l}\text { Protein subunit, } \\
\text { conjugated }^{\mathrm{d}}\end{array}$ & 25 April 2021 & 24,000 & 7 November 2021 & $\operatorname{Iran}(65)$ \\
\hline $\begin{array}{l}\text { NCT04904549 } \\
\text { PACTR202106588702901 }\end{array}$ & $\begin{array}{l}\text { Sanofi Pasteur } \\
\text { (France) }\end{array}$ & $\begin{array}{l}\text { Adjuvanted } \\
\text { recombinant } \\
\text { protein: } \\
\text { monovalent and } \\
\text { bivalent }\end{array}$ & 26 May 2021 & $21,046^{\mathrm{e}}$ & 8 October 2021 & $\begin{array}{l}\text { Colombia (64), } \\
\text { Ghana (7), } \\
\text { Honduras (39), } \\
\text { India (54), Japan } \\
\text { (79), Kenya (7), } \\
\text { Nepal (29), USA } \\
(68)\end{array}$ \\
\hline NCT04922788 & Nanogen (Vietnam) & Protein subunit & 7 June 2021 & 13,000 & 11 June 2021 & Vietnam (66) \\
\hline $\begin{array}{l}\text { NCT04904471 } \\
\text { PACTR202103845381761 }\end{array}$ & WestVac (China) & $\begin{array}{l}\text { Recombinant (Sf9 } \\
\text { cells) }\end{array}$ & 18 June 2021 & 40,000 & 2 November 2021 & $\begin{array}{l}\text { Indonesia (47), } \\
\text { Kenya (7), Mexico } \\
\text { (58), Philippines } \\
\text { (30) }\end{array}$ \\
\hline PACTR202105817814362 & $\begin{array}{l}\text { South African } \\
\text { Medical Research } \\
\text { Council }\end{array}$ & $\mathrm{mRNA}^{\mathrm{g}}$ & 13 July 2021 & 14,000 & 3 November 2021 & $\begin{array}{l}\text { Bostwana (32), } \\
\text { Kenya (7), Malawi } \\
\text { (5), South Africa } \\
\text { (27), Swaziland } \\
\text { (NP), Uganda } \\
\text { (8), Zambia (2), } \\
\text { Zimbabwe (23) }\end{array}$ \\
\hline $\begin{array}{l}\text { NCT05005559 } \\
\text { IRCT20150303021315N24 }\end{array}$ & CinnaGen (Iran) & Protein subunit & 7 August 2021 & 16,876 & 5 October 2021 & $\operatorname{Iran}(65)$ \\
\hline $\begin{array}{l}\text { NCT05096845 } \\
\text { PACTR202107562417077 }\end{array}$ & Livzon (China) & Fusion protein & 25 August 2021 & 22,500 & 27 October 2021 & Philippines (30) \\
\hline NCT04847102 & $\begin{array}{l}\text { Walvax } \\
\text { Biotechnology } \\
\text { (China) }\end{array}$ & mRNA & $\begin{array}{l}27 \text { August } 2021 \\
\text { [16] }\end{array}$ & 28,000 & 17 May 2021 & $\begin{array}{c}\text { Indonesia [16] (47), } \\
\text { Mexico [16] (58), } \\
\text { Nepal (29) [16] }\end{array}$ \\
\hline \multicolumn{7}{|l|}{ Trials to be started } \\
\hline NCT04852705 & $\begin{array}{l}\text { Shenzhen Kangtai } \\
\text { Biologicals } \\
\text { (China) }\end{array}$ & $\begin{array}{l}\text { Inactivated (Vero } \\
\text { cell) }\end{array}$ & $\begin{array}{l}\text { May } 2021 \text { (esti- } \\
\text { mated) }\end{array}$ & 28,000 & 22 April 2021 & $\begin{array}{l}\text { Malaysia [17] (78), } \\
\text { Philippines [17] } \\
\text { (30), Ukraine [17] } \\
\text { (28) }\end{array}$ \\
\hline NCT04984408 & $\begin{array}{l}\text { International } \\
\text { Vaccine Institute } \\
\text { (UNDP) }\end{array}$ & $\begin{array}{l}\text { Inactivated (Vero } \\
\text { cell) }\end{array}$ & $\begin{array}{l}1 \text { October } 2021 \\
\text { (estimated) }\end{array}$ & 8,825 & 16 August 2021 & Mozambique (15) \\
\hline NCT05096832 & Livzon (China) & Fusion protein & $\begin{array}{l}31 \text { October } 2021 \\
\text { (estimated) }\end{array}$ & 10,722 & 29 October 2021 & Pakistan (35) \\
\hline
\end{tabular}

$N P$, not provided; UNDP, United Nations Development Programme (Seoul, South Korea)

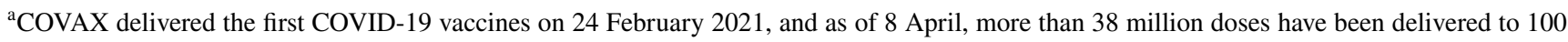
economies [13], whereas China had exported over 115 million doses by 1 April[14]

${ }^{b}$ Percentage of the population that were at least partially vaccinated as of 16 November 2021[15]

${ }^{\mathrm{c}}$ Data from Iranian Registry of Clinical Trials

${ }^{\mathrm{d}}$ This is the Soberana 02 (Cuba) vaccine

${ }^{\mathrm{e}}$ The trial aimed to recruit 37,430 participants when it was started in the USA

${ }_{\mathrm{f}}^{\mathrm{A}}$ All American and Japanese sites have stopped recruitment, but are active

${ }^{\mathrm{g}}$ This is the Moderna (USA) vaccine

${ }^{\mathrm{h}}$ The control group will receive Flu quadrivalent vaccine instead of inert placebo

${ }^{\mathrm{i}}$ This is a BBIBP-CorV (Sinopharm, China) vaccine 
Only placebo-controlled RCTs that started after 1 April 2021 are described. These are trials that were likely started after, at least, some participating countries had the opportunity to access to a certain number of authorized COVID-19 vaccine doses. These trials are sponsored by local or foreign companies or organizations and are placed in four continents. Of these RCTs, two of them deserve a reflection.

First, the one to be conducted in eight Sub-Saharan countries is aimed to assess SARS-CoV-2 variants of concern (PACTR202105817814362). The trial has been approved by 12 local research committees in five participating countries and by the UCSF Human Research Protection Program institutional review board since the trial is sponsored by the US NIAID. The approved protocol states that, at the first set of vaccinations, 7,000 participants will be allocated to receive the two vaccine doses, whereas the other 7,000 will receive two placebo injections; some 2 to 4 months later, in a doubleblind fashion, participants will be crossed over to receive two placebo injections or two vaccine doses. The protocol states that if an authorized vaccine becomes available, participants will have the option of being unblinded and receive the authorized vaccine. Unblinding is not reported in the information posted on the registries for the other trials mentioned in Table 1, except for the one to be discussed below.

Second, the trial sponsored by Sanofi Pasteur (NCT04904549) was started in the USA in June 2021. This trial should have not been approved neither by American institutional review boards nor by Japanese research ethics committees (RECs), since clinical equipoise was not present at the time the trial protocol was reviewed in these countries [18]. All US sites have stopped recruitment eight weeks after the trial was started, as did the Japanese centers shortly after. As happened in the Sub-Saharan trial mentioned above, participants can request unblinding. This trial has a number of recruiting sites in Africa, Asia, and Latin America. The conduct of this trial in Colombia raises ethical concerns, since with $64 \%$ of the population being at least partially vaccinated [15] and with an adult population of $69 \%$ of the total [19], it might have enough doses to vaccinate all adults.

All trials that are being sponsored by Chinese companies are being (or will be) conducted outside China. Having $82 \%$ of all Chinese population at least partially vaccinated [15], and being adults about $77 \%$ of the population [19], it is almost certain that any Chinese adult could have access to any available COVID-19 vaccine. So, no new placebocontrolled RCTs should be conducted in healthy naïve adults in China. All participating countries of these trials have a limited percentage of their populations partially vaccinated against SARS-CoV-2, so the conduct of these placebocontrolled RCTs is ethically sound. However, there are two exceptions. Thus, sites from Malaysia and Mexico should not participate since, with $78 \%$ and $58 \%$ of their populations partially or fully vaccinated [15], so no adult should have difficulty getting vaccinated with a temporarily authorized COVID-19 vaccine. Recruitment to these trials should be stopped and participants should have the option of being unblinded and receiving a vaccine out of study something that is uncertain since there is no information available about it.

The same approach should be applied to local companies from Iran and Vietnam that are conducting placebocontrolled RCTs in their countries where $65 \%$ and $66 \%$ of their populations have been partially or fully vaccinated.

Finally, WHO-sponsored Solidarity Vaccine Trial (ISRCTN15779782) is an adaptive RCT [20] that was started in September 2021 with three COVID-19 vaccine candidates to be assessed vs placebo. These are Codagenix and Serum Institute of India live-attenuated virus vaccine (Covi-Vac); Medigen, Dynamax, and NIAID protein subunit vaccine (MVC-COV1901); and Arcturus mRNA vaccine (ARCT-154) [11].

\section{Comparative immunogenicity RCTs in current COVID-19 vaccine candidates' development}

Currently, there is a window of opportunity to conduct placebo-controlled RCTs in settings with limited access to authorized COVID-19 vaccines before immunogenicity trials are widely implemented. And this will happen once correlates of protection are accepted by the scientific community and regulatory agencies, something that has not happened yet although several preliminary reports on correlates of protection to a few vaccines have been published [21-25]. An important concern that has been recently flagged is that immunogenicity RCTs comparing a novel vaccine candidate with an authorized vaccine might find the issue of not having these latter available for the conduct of comparative RCTs, since the use of available temporarily authorized COVID19 vaccines are restricted to fulfill public health needs [26]. Yet currently, there are three phase 3 immunogenicity RCTs assessing vaccine candidates vs the AstraZeneca vaccine in healthy adults: Valneva's inactivated virus vaccine (France, NCT04864561, $n=4,019$, started in April); SK Bioscience's protein subunit vaccine (South Korea, NCT05007951, $n=3,990$, started in August); and Medigen's protein subunit vaccine (Taiwan, NCT05011526, $n=1,020$, not yet recruiting). In addition, in September, one immunogenicity RCT (CTRI/2021/08/036074; $n=2,140$ ) started in India assessing Biological E's protein subunit vaccine (Corbevax) vs Covishield (the AstraZeneca vaccine manufactured by Serum Institute of India), whereas one month later, a RCT (NCT05077176; $n=7,300$ ) was started to assess Health Institutes of Turkey inactivated virus vaccine (Turkovac) vs Coronavac (Sinopharm inactivated vaccine). 


\section{Conclusion}

The lack of enough available temporarily authorized COVID-19 vaccines to immunize all their naïve healthy adult populations is the main problem of many low- and middle-income countries regarding the COVID-19 pandemic. Until this huge public health issue is solved and unto the scientific and regulatory acceptance of correlates of protection for temporarily authorized COVID-19 vaccines, denying the conduct of ethically and scientifically sound placebo-controlled RCTs with novel vaccine candidates in countries with limited access to authorized COVID-19 vaccines prevents both having these countries involved in a type of research that is of high social value for their communities and building capabilities in vaccine development that could be critical in future pandemics.

\section{Declarations}

Conflict of interest The author declares no competing interests.

\section{References}

1. Maggioni AP, Andreotti F (2021) Efficacy of COVID-19 vaccines against active comparators or inert placebos. JAMA Intern Med 181:1257-1258

2. Knottnerus JA (2021) New placebo-controlled Covid-19 vaccine trials are ethically questionable; it's now about comparative effectiveness and availability of registered vaccines. J Clin Epidemiol 133:175-177

3. Hemkens LG, Goodman SN (2021) Randomized COVID-19 vaccination rollout can offer direct real-world evidence. J Clin Epidemiol 138:199-202

4. Raus K, Mortier E, Eeckloo K (2021) Ethical reflections on Covid19 vaccines. Acta Clin Bel May 19:1-6. https://doi.org/10.1080/ 17843286.2021.1925027. Online ahead of print. PMID: 34008482

5. Bonati M (2021) Restrictions on the use of placebo in new COVId-19 vaccine trials. Eur J Clin Pharmacol 30;1-2. https:// doi.org/10.1007/s00228-021-03203-z. Online ahead of print

6. Dal-Ré R (2021) Clinical equipoise in COVID-19 vaccine candidate trials. J Clin Pharmacol 61:1249-1250

7. Padma TV (2021) COVID vaccines to reach poorest countries in 2023 - despite recent pledges. Nature 595:342-343

8. Dal-Ré R, Bekker LG, Gluud C, Holm S, Jha V, Poland GA et al (2021) Ongoing and future COVID-19 vaccine clinical trials: challenges and opportunities. Lancet Infect Dis 21:e342-e347

9. Sisa I, Noblecilla E, Orozco F (2021) Rationale to continue approving placebo-controlled COVID-19 vaccine trials in LMICs. Lancet 397:878

10. Stoehr JR, Jahromi AH, Thomason C (2021) Ethical considerations for unblinding and vaccinating COVID-19 vaccine trial placebo group participants. Front Pub Health 9:702960

11. World Health Organization. COVID-19 vaccine tracker and landscape publication. 16 November 2021. https://www.who.int/ publications/m/item/draft-landscape-of-covid-19-candidate-vaccines
12. World Health Organization. International Clinical Trials Registry Platform. Search portal. 16 November 2021. https://trialsearch. who.int/

13. World Health Organization. COVAX reaches over 100 economies, 42 days after first international delivery. 8 April 2021. https:// www.who.int/news/item/08-04-2021-covax-reaches-over-100economies-42-days-after-first-international-delivery

14. China exports half its vaccine production: the UK and US, almost none. Chart. CGTN. 1 April 2021. https://newseu.cgtn.com/news/ 2021-04-01/China-exports-half-its-vaccines-the-UK-and-U-Salmost-none-Chart-Z3YKzBnOnK/index.html

15. Our World in Data. COVID-19 Data Explorer. Share of people vaccinated against COVID-19. 16 November 2021. https://ourworldindata. org/explorers/coronavirus-data-explorer?zoomToSelection= true $\&$ facet $=$ none $\&$ pickerSort $=$ asc $\&$ pickerMetric $=$ location $\&$ Interval $=7$-day + rolling + average $\&$ Relative + to + Population $=$ true \&Align+outbreaks $=$ false $\&$ country $=\mathrm{CHN} \sim \mathrm{USA} \sim \mathrm{IDN} \sim \mathrm{JPN} \sim$ $\mathrm{ETH} \sim \mathrm{PHL} \sim \mathrm{VNM} \sim \mathrm{TUR} \sim \mathrm{IRN} \sim \mathrm{ZAF} \sim \mathrm{KEN} \sim \mathrm{HND} \sim \mathrm{MWI} \sim \mathrm{MOZ} \sim$ $\mathrm{UKR} \sim \mathrm{UGA} \sim \mathrm{ZMB} \sim \mathrm{ZWE} \sim \mathrm{BWA} \sim \mathrm{COL} \sim \mathrm{MYS} \&$ Metric $=$ People+ vaccinated $+\% 28$ by + dose $\% 29$

16. Pinghui Z. Coronavirus: Indonesia, Mexico approve late-stage trials of Chinese mRNA vaccine hopeful. South China Morning Post. 1 September 2021. https://www.scmp.com/news/china/science/ article/3147168/coronavirus-indonesia-mexico-approve-latestage-trials-chinese

17. Biokangtai COVID-19 vaccine approved for phase III clinical trials in the Philippines. 2 August 2021. https://en.biokangtai.com/ N185.html

18. Dal-Ré R, Caplan AL (2021) Current COVID-19 vaccine trials in high-income countries: are placebo-controlled trials ethical? Clin Microbiol Infect 27:1565-1567

19. Population pyramids of the world (2019) PopulationPyramid.com. https://www.populationpyramid.net/

20. World Health Organization. Solidarity Trial Vaccines. An international randomized trial of candidate vaccines against COVID-19. Geneva. 14 June 2021. V 2.0. https://cdn.who.int/media/docs/defaultsource/blue-print/who-covid-2019_solidarityvaccinetrial_14-june2021_clean_for-registry.pdf?sfvrsn=77b2110a_11\&download=true

21. Khoury DS, Cromer D, Reynaldi A, Schlub TE, Wheatley AK, Juno JA et al (2021) Neutralizing antibody levels are highly predictive of immune protection from symptomatic SARS-CoV-2 infection. Nat Med 27:1205-1222

22. Earle KA, Ambrosino DM, Fiore-Gartland A, Goldblatt D, Gilbert $\mathrm{PB}$, Siber GR et al (2021) Evidence for antibody as a protective correlate for COVID-19 vaccines. Vaccine 39:4423-4428

23. Lustig Y, Sapir E, Regev-Yochay G, Cohen C, Fluss R, Olmer $\mathrm{L}$ et al (2021) BNT162b2 COVID-19 vaccine and correlates of humoral immune responses and dynamics: a prospective, singlecentre, longitudinal cohort study in health-care workers. Lancet Respir Med 9:999-1009

24. Feng S, Phillips DJ, White T, Sayal H, Aley PK, Bibi S et al (2021) Correlates of protection against symptomatic and asymptomatic SARS-CoV-2 infection. Nat Med. 29 September. https:// doi.org/10.1038/s41591-021-01540-1. Online ahead of print

25. Gilbert PB, Montefiori DC, McDermott A, Fong Y, Benkeser D, Deng $W$ et al (2021) Immune correlates analysis of the mRNA1273 COVID-19 vaccine efficacy trial. medRxiv preprint 15 August. https://doi.org/10.1101/2021.08.09.21261290

26. Saville M (2021) COVID-19: release approval vaccines for trials of new ones. Nature 597:178

Publisher's Note Springer Nature remains neutral with regard to jurisdictional claims in published maps and institutional affiliations. 